\title{
Medicinal Properties of Augustine
}

\author{
Nicholas Barron
}

Southern Illinois University at Carbondale

\section{Introduction}

Medicine cures the sickness of the human body, but what is appropriate to remedy the maladies and pains of the human soul? Martha Nussbaum, in her book, The Therapy of Desire, responds to this question by arguing that philosophy has the ability to restore health to the human soul. What's more, Nussbaum also argues that various Hellenistic schools formulated "medical moral philosophies" which had precisely this therapeutic objective. She asserts that examples of medical moral philosophies would include the systems of the Epicureans, Stoics, and Skeptics, but Nussbaum precludes the addition of what she calls the "Augustinian Christian ethic" from the list of medical moral philosophies. Nussbaum claims that the Augustinian Christian ethic cannot be considered medical because it fails to arise from human needs, desires, and aspirations. This paper will undertake to explain why this position should be rethought.

In this paper, I will explain why the Augustinian Christian ethic can indeed be considered a medical moral philosophy concerned with producing happiness and a healthy soul. This paper will maintain that the Augustinian Christian ethic satisfies all the common characteristics associated with any medical moral philosophy. Furthermore, this paper will conclude that Nussbaum's primary problem is one of "human good", since as Nussbaum asserts, the Augustinian ethic fails to place the locus of the human good squarely within human being itself. Consequently, she argues, God's will and grace must be considered the locus of the human good. This conclusion should be reconsidered, and this paper will show, by way of examining the Augustinian ontology, along with the role of grace in the Augustinian world view, that indeed human being and human experience are the centers out of which human well-being and happiness flows. And so, in the final 
analysis, this paper will demonstrate how Nussbaum's primary problem with the Augustinian ethic is without merit.

In order to support these claims, I will examine Nussbaum's general position regarding eudaemonia and its relationship to medical moral philosophies. Furthermore, I will also examine the ontological underpinnings of Augustine's ethic along with other pertinent dimensions of the Augustinian moral system. The salient elements of the Augustinian ethic to be discussed will include Augustine's thoughts on the subjects of: eudaemonia, "Christian" virtue, of which "Christian" wisdom is an integral part, justice, and grace. By way of these discussions it should become more evident that this ethic is naturally inclined to being considered a medical moral philosophy. Furthermore, Augustine's Confessiones will be examined and interpreted as a case in point of an exemplum. And finally, after a discussion of Augustine's ontology and views on grace are completed, I will respond to two problematic issues. First I will reconcile what Nussbaum's fails to reconcile: God's grace within the Augustinian philosophy and a human good independent of this very grace. Secondly, I will discuss the otherworldly dimension of Augustine's eudaemonistic project.

\section{Section I: Nussbaum's Views Concerning Medical Moral Philosophies and Why the Augustinian Ethic Fails to be Considered as a Medical Moral Philosophy}

Nussbaum claims that the thinkers of the Hellenistic period believed the goal of human life-eudaemonia or happiness-was itself that which provided for the well-being of the human soul. Philosophy, then, was the medication necessary to cure the diverse disorders and ailments of the human soul. The ethical and the medical were one:

In short, there is in this period broad and deep agreement that the central motivation for philosophizing is the urgency of human suffering, and the goal of philosophy is human flourishing, or eudaemonia.' 
Nussbaum argues that ethics is a matter of looking into the lives of human beings and discerning those prescriptions that guide our lives towards happiness and the health of the soul. Consequently, ethical truths are the "shoulds" and "oughts" which arise directly from the needs, wishes, and aspirations of human life. ${ }^{2}$ In her book, Nussbaum contrasts this view of medical ethics with other conceptions of ethics, including the Platonic conception, traditional social belief, and, finally, the Augustinian Christian conception. ${ }^{3}$ But in this paper, I am concerned with and will briefly sketch out only her thoughts on the latter ethic.

Nussbaum claims that the Augustinian Christian ethic, like the Platonic and traditional, does not fit the medical mold. Similar to the Platonic, she maintains that the Augustinian Christian ethic is divorced from the realm of human being and experience.

Nussbaum writes that the Augustinian ethic is, at its heart, a matter of submitting one's will to the will of God. According to this ethic, ethical norms arise from the wants or desires of God, and, in order to be ethical-in order to do what one ought-one simply needs to conform their wants to God's wants. Simply, God willed what humans should do, and humans should conform their will to God's. Nussbaum makes comment to this point when juxtaposing the Augustinian conception of ethics with the Platonic. She writes of the Augustinian ethic:

We get a similar picture by a different route in the Augustinian version of Christian ethics. God has set up certain ethical standards; it is our job to do what God wants. ${ }^{4}$

According to the Augustinian ethic, humans must have help in their pursuit to live ethically. Truth and God's grace provide succor in this effort, however, it is not guaranteed that we will be able to recognize truth or receive grace. Because of this, it is not certain that we will be able to conform our will to God's and live ethically. Again, Nussbaum remarks:

But we may or may not be endowed with the capability of seeing, or wanting what God wants. 
Truth and God's grace are out there; but the ability to see ethical truth or reach for God's grace is not something we can control. There is, therefore, no reliable method by which we can construct an ethical norm from the scrutiny of our deepest needs and responses and desires. ${ }^{5}$

Nussbaum concludes that human needs and aspirations cannot be the source of human good for two reasons. First, God's will provides the standard for ethical decision-making. According to this conception, to be ethical is a matter of wanting, too, what God has already decided that one ought to want. God provides the ethical norms to be followed and so can be considered the locus of the ethical. Secondly, we cannot derive reliable ethical norms out of our own human experience. We cannot use our human aspirations and desires to create a sound set of ethical truths to guide us to the authentically good life. This is so due to the human inability to recognize the truth and to the unpredictability of the gift of illuminating grace. As Nussbaum points out, truth and God's grace exist, but there is no assurance that we can identify the one or obtain the other. The examination of human experience, including our desires, wishes, and aspirations, may turn out to yield only erroneous conclusions regarding ethical standards due to human ignorance and the privation of illuminating grace. For Nussbaum, this culminates in the real possibility that for Christians, "digging more deeply into ourselves is not the right way to proceed in ethical inquiry. For the possibility must always be left open that everything we are and want and believe is totally in error."6

At this point, Nussbaum contends that the good, as contained in God's will, is profoundly separate from human experience and, at the same time, is the only infallible grounds for ethical truth. As a result, Nussbaum argues that this ethic, at its core, entails what she calls this fundamental "structural idea: the idea of the radical independence of true good from human need and desire."7 In the final analysis, then, she concludes that the Augustinian Christian ethic cannot qualify as a medical moral philosophy because it fails to arise out of the human being and its experience. The basis of this ethic is to be found in the will of a radically independent Other. 
Any medical moral philosophy has, as its primary objective, living well. But in order to achieve this objective, Nussbaum concludes that a vital reconstruction of the human soul is first needed. This reformation demands a transformation of belief, desire, and emotion. ${ }^{8}$ Nussbaum points out that this necessity is stressed in the various medical outlooks of the Hellenistic schools, and, on that account, she believes that any medical ethic must include first recognizing and then changing these various diseased beliefs and desires. To the end of recognizing and sorting out problematic beliefs and desires, Nussbaum believes that medical moral philosophies, uniquely, have developed three common "therapeutic tools". The purpose of these therapeutic tools is essentially development and guidance. These tools guide the human being towards health by means of identifying and purging various unhealthy convictions, appetites, and desires. Medical moral philosophies, then, will universally formulate "therapeutic tools" which include:

1. A tentative diagnosis of disease, of the factors, especially socially taught beliefs, that are most prominent in preventing people from living well. 2. A tentative norm of health: a conception (usually general and to some degree open ended) of the flourishing and complete human life.

3. A conception of proper philosophical method and procedure."

Next, Nussbaum believes that all medical moral philosophies will have other unique features that differentiate them from other moral philosophies, including:

4. Arguments have a practical goal: they are directed at making the pupil better, and can be assessed for their contribution to this end.

5. They are what we might call value-relative: that is, at some level they respond to deep wishes or needs of the patient and, again, are to be assessed in accordance with their success in doing this.

6. They are responsive to the particular case: just 
as a good doctor heals case by case, so good medical arguments responds to the pupil's concrete situation and needs."

These features, too, have specific objectives. They help to edify the human person and encourage development in the good. They also aim at making the moral philosophy relevant and responsive to the individual and their particular situation..

As alluded to earlier, a shared feature of medical moral philosophies is their intention and purpose which is the transformation of belief, desire, and passion. The objective of any medical moral philosophy is the improvement of people, not merely ethically or morally, but also physically and spiritually. A necessary means to achieving this end, Nussbaum points out, includes the use of what she calls an "exemplum". For Nussbaum, the exemplum is an essential device for the amelioration of people's lives since it has the distinctive ability to intimately relate to the lives of its readers. Exempla are devices, unique to medical moral philosophies, which express the moral thoughts of a system. But they do much more than pass along intellectual ideas and arguments considering the fact that they cover the ideas and arguments within a highly personal, highly intimate surfacing, thus making the thoughts more applicable to the concrete lives of people. Exempla instruct in right behavior, but they also paint a picture for the reader expressing more about right action and the well-lived life than can be communicated by intellectual ideas and arguments alone. The exemplum is an important tool since it is able to invaluably promote teaching, connection, relevance, and reflection. Nussbaum writes:

The importance of exempla and narrative in Stoic teaching is, then, closely connected to the importance Stoics attach to concreteness. And this itself seems to have more than one source. One as we have seen is motivational: we cannot really change a personal soul without engaging it in a highly personal, vivid, and concrete way. ${ }^{12}$ 


\section{Section II: The Augustinian Ethic and its Ontological Underpinnings}

The Augustinian moral theory is intimately connected with the Augustinian ontology. The human good, for Augustine, is not disconnected from both the individual's being and the greater environment within which the human person exists. Goodness is part of both persons and their world. Hence, ontology is important for Augustine and constitutes the starting point for any reasonable introduction to Augustine's moral theory. Moreover, understanding Augustine's ontology constitutes the first step in refuting Nussbaum's concerns regarding medical moral philosophies and the Augustinian ethic.

Vernon Bourke concludes that Augustine's ontological views are best formulated by responding to three distinct questions. When inquiring about the nature of the temporal world and created being, Augustine believes it is necessary to ask of all created being: "does it exist, what is it, and does it endure?"13 Bourke claims that Augustine's analysis of created being constitutes a response to these specific questions.

Augustine responds to the first ontological question asked, "does it exist?" with the reply that temporal being always includes "measure", while Augustine later interprets measure to mean "existence" or "esse." In addition, esse is more precisely understood by Augustine to denote existence qualified as unity. For Augustine's ontology, then, a characteristic feature of being is measure or existence, understood always in terms of unity. To be, is to be one. To be, is to exist as a unified whole. Bourke states:

It has been suggested by one interpreter that the import of the first member of the triad is existential. It is possible here that Augustine is trying to get at the principle of existence in each instance of being. If so then modus (which is sometimes named esse) may approximate the existential characteristic of every entity. Fundamental to this interpretation is the fact that the unity which Augustine attributes to each being is not an abstrac- 
tion but rather the concrete fact that to be is to be one. ${ }^{15}$

The idea of species addresses Augustine's second ontological question, "what is it?" Species is the formal principle in all individual unities which differentiate individual unities into unique classes or kinds. Species separates individuals into larger groups which themselves contain numerous individuals, all of the same kind.

Finally, to the third of Augustine's ontological questions, "does it endure?", Bourke notes, ordo responds. The word ordo signifies what we perceive simply as order. Augustine's writings assert that there is order and arrangement in different domains, such as being, space, time, or nobility, and in each of these graduated domains there are hierarchies and places of greater and lesser goodness, value, and importance. In addition, Bourke maintains that the term ordo must be understood as having teleological overtones. Ordo, then, is a term which implies this graduated order, but it also implies the notion that each thing has its specific place within this graduated order. The teleological overtones intimate that each individual within this graduated whole is ordered towards a specific final end-understood in terms of value as its good.

Bourke observes that in De Genesi ad Litteram, Augustine explains that a thing's weight or pondus appropriates it towards its good, its final place of rest and stability. Because of this, each individual within the ordered whole has an intrinsic tendency towards its naturally designed good and place of repose and stability. Therefore, for Augustine, within the graduated order of the whole of being, space, time, and nobility an individual's weight or pondus inclines it naturally to its divinely pre-ordained terminus, and as a result, this natural terminus is the good which the individual has been designed to incline itself towards. To abide in being then, for Augustine, is not merely to persist or persevere in existence, but it is sometimes to accept and always conform to a thing's rightful place in that pre-determined order within which an individual thing finds itself. To abide includes a thing's living within its pondus, realizing and participating in its proper, predetermined end and good. To sum up, in Bourke's words, for a 
thing to endure or abide in being is, "not merely to last but to achieve that ideal perfection in the whole of things which is the divine plan of Providence."16

This discussion of Augustine's ontology brings to light this idea: beings exist always as individual unities which are part of a class of like individuals, and which subsist within an order that has been pre-arranged within a gradated whole. Hence, within the nature of the world, both beings and their respective goods are part of the same whole. Created beings have been constructed with an inherent attraction to their unique perfection and good, and so Augustine's ontology reaffirms that God has willed a good world, a world in which both individuals and their complementary goods are coterminous. At the same time, God has also willed a world in which all of these same individuals appear to be inclined to their natural respite and stability.

\section{Section III.a: Justice, Order and the Ramifications of these in the Augustinian Ethic}

In De Civitas Dei, Augustine develops a general theme at the heart of his ethic. This text delineates two basic camps: For humankind those driven toward the earthly and material or those driven towards God and the spiritual.

There exist no more than two kinds of society, which according to our scriptures, we have rightly called the two cities. One city is that of the men who live according to the flesh. The other is of men who live according to the spirit. Each of them chooses its own kind of peace and, when they attain what they desire, each lives in the peace of their own choosing. ${ }^{17}$

The basis of the two cities and types of persons is the direction of their love. The cities or persons which focus upon God and direct their wills and loves towards God are considered good, while those cities and persons which direct their wills and loves towards the world are considered sinful. 
What we see, then, is that two societies have issued from two kinds of love. Worldly society has flowered from a selfish love which dared to despise even God, whereas the communion of saints is rooted in a love of God that is ready to trample on self. In a word, this latter relies on the Lord, whereas the other boasts that it can get along by itself. ${ }^{18}$

The well directed loves illustrative of the heavenly city and person prompt both peace and joy, but, at the same time, they also are the end result of justice. And it is precisely this justice which orders or arranges the various parts of the human being back towards its good and proper place of rest and stability. Justice is that virtue which liberates the human person and reunifies this person with their inherent drive towards their good. In other words, justice orders the human in such a way so as to find eudaemonia and health.

Justice, for Augustine, is the result of the city or person being ruled by the one supreme God and His grace so that:

...it sacrifices to none but him, and whereby, in all the citizens of this obedient city, the soul consequently rules the body and reason the vices in the rightful order, so that as the individual just man, so also the community and people of the just, live by faith, which works by love, that love whereby man loves God as he ought to be loved, and his neighbor as himself. ${ }^{19}$

The essence of Augustinian justice can be understood as consisting in right order since this virtue is concerned with the ordering of the various parts within the whole: God, soul, reason, body, vices, and loves. But justice also includes the right ordering of other objects. It includes right order in that the worse is controlled by the better, all that is equal is given its proper due and is dominated neither by that which is equal to it or lesser than it, and all the better, the equal and the lesser is regarded as it should be. Justice, too, dictates that the incorruptible, because of its superior 
nature, is to be more esteemed than the corruptible. The same is true of the eternal. The eternal is recognized as superior to the ephemeral. God's created world is just, and as a result, in God's created world, the better rules the worse, the superior incorruptible controls the inferior corruptible, and the more fully real, the eternal, has dominion over the material and transitory. ${ }^{20}$

There are also consequences to this just ordering. For Augustine, justice prompts peace and joy. Peace and joy, then, as an effect of justice, are the results of proper order. God, the person, the soul, the loves, the reason, the body, the equal and the unequal, the better and the worse, the temporal and the eternal all have their appropriate place within the order of the whole of things. To be just is to live within this order. It is to establish a consonant relationship between yourself and the whole of your environment.

\section{Section III.b: The Augustinian Account of Justice and its Relationship to Nussbaum's Medical Moral Paradigm- Injustice and Justice as Diseased and Salutary}

Augustine's ethic advances a conception of a diseased soul ${ }^{21}$, along with the factors producing this condition. As I have pointed out, Augustine's ethic concerns itself with these primary themes: towards which direction are the human loves oriented, what is it that we desire most, and do we desire and love rightly? For Augustine, the human will and loves could be and always are oriented towards either the transitory world or the abiding God. As a result, sin can be interpreted accordingly. Sin can be viewed as a problem of injustice and a baneful turning of the self's loves. De Libero Arbitrio supports this view. In this dialogue, Augustine comments that justice is, itself, a manifestation of the eternal, along with its order and law. Because of this, to turns one's loves away from their proper orientation and towards the temporal is to fail to participate in justice. To turn from the eternal order is to turn from justice itself, and this sinful turning has a natural consequent. This sinful turning produces disease, discord, and misery. ${ }^{22}$ Sin consists of a deviation from the established, just equilibrium. It is a diseased turning; the sinful alignment of the person. And this diseased alignment is the product of three things: an unhealthy ar- 
rangement of the person in relation to God and His creation, an unhealthy arrangement of the soul in accord with the body, and an unhealthy arrangement of reason in accord with vice. So an unhealthy soul is a soul which fails to conform to the order of eternal justice and its immutable laws. For Augustine, there is most certainly a standard for disease in his ethic, and in short, this disease, looked at microscopically, entails being displaced from where you belong, thereby disturbing the equilibrium inherent in your person, but also, viewed macroscopically, it is to upset the ordered balance of the world. ${ }^{23}$

Conversely, the standard of health can be understood to include justice. ${ }^{24}$ The justly ordered life is the life avoiding the aforementioned disorders, anxieties, and diseases of the human soul. If the soul is not just, then the soul will be sick. Accordingly, the healthy soul is naturally the soul without afflictions, and it is at peace and is both joyful and happy. Moreover, the healthy soul, for Augustine, is the soul that finds freedom from itself. This healthy soul finds liberation through loving rightly and accepting its rightful place in the created order. It has, speaking metaphorically, "found its way home", and reunified itself with its pondus, its natural tendency to return to it place of repose and predetermined good.

\section{Section IV.a: Eudaemonia and Wisdom in the Augustinian Ethic}

Augustine's ethic can be considered eudaemonistic. Humans, by nature, he believes, pursue the good. Humans naturally seek their good, and this good can be re-articulated as happiness. Therefore, humans naturally desire happiness, and it is happiness which, alone, gives them true satisfaction..$^{25}$

Augustine argues that happiness includes a right satisfaction, but a right satisfaction abiding in nature. God solely satisfies this requirement.

In no way do we doubt that if anyone has decided to be happy, he must secure for himself what is permanent, what no misfortune, however grave, 
can snatch away. Therefore, whoever possesses

God is happy. ${ }^{26}$

Happiness is a satisfaction by means of the eternal God. But, in De Beata Vita, Augustine explores the nature of happiness more fully and concludes that happiness should likewise be understood as the "fullness" of satisfaction. Moreover, this fullness of satisfaction can rightly be understood as "wisdom", while wisdom, consists of a satisfaction of desire between the extremes of excess and deficiency and so has the quality of right measure or proportion. As such, wisdom is a measuring, a measuring the desires rightly. Because of this, Augustine comments that the wise man has a full soul and lacks nothing and so is the rightly satisfied man.

We should see who is not in need, for he will be wise and happy. 'Folly' is a synonym for 'need' and this word usually signifies a kind of sterility and lack. Wisdom is fullness and in fullness there is measure; therefore the measure in the mind is wisdom. For wisdom is nothing but the measure of the soul, that is, that by which the mind is liberated so that it neither runs over into too much nor falls short of fullness. ${ }^{27}$

As is obvious from this passage, it appears that to Augustine wisdom frees the soul from the extremes enslaving it. Wisdom is that proper measure ${ }^{2 x}$ of gratification fostering the liberation of the soul by averting its demise through the surplus or paucity of desire. Wisdom, though, is not merely some right formula of satisfaction existing independently from God. Wisdom can have no nature separate from God since Augustine argues in this dialogue that there is no wisdom other than the wisdom of God. Furthermore, what we call wisdom, he says, is actually truth. For Augustine, this wisdom or measure is the very same truth existing through God the Father, Son, and Holy Spirit. It appears that the authentic satisfaction of the soul consists in acquiring, enjoying, and living within this wisdom and truth whose source is the triune God. 
This therefore, is the complete satisfaction of souls, that is the happy life: to know precisely and perfectly Him through whom you are led into the truth, the nature of the truth you enjoy, and the bond that connects you with the Supreme Measure! ${ }^{29}$

In Augustine's writings, wisdom is additionally presented as dynamic process. Wisdom includes following what Augustine refers to, in De Libero Arbitrio, as the "right road of life." Persons can mature and advance in wisdom and this development is expressed by Augustine in the metaphor of "via" or road. He explains to his readers that the wisdom which leads to happiness must first include an idea of via. ${ }^{31}$

Insofar as all men seek the happy life, they do not err. Insofar as each man fails to follow the road of life that leads to happiness, although he may confess and profess that he is unwilling to arrive anywhere except at happiness, he is in error. His error is that he follows something that does not lead where he wishes to arrive. The greater his error on the road of life, the less his wisdom, and the farther he is from the truth in which the highest good is discerned and grasped. Moreover, when the highest good has been pursued and obtained, each man becomes happywhich beyond a doubt is what we all wish. Just as it is agreed that we all wish to be happy, so it is agreed that we all wish to be wise, since no one without wisdom is happy. No man is happy except through the highest good, which is to be found and included in that truth which we call wisdom. ${ }^{31}$

The dialogues only up to this point can give the reader a false impression about Augustine's views on the nature of the happy life. Up to this point, De Beata Vita reasons that happiness is to be acquired by means of the intelligence. After all, it appears that in 
these dialogues Augustine reaches the conclusion that the good life can be considered mainly the result of knowledge-the knowledge of the moderate choice and following De Libero, the moderate choice realized gradually. But Monica has something important to contribute at the end of the discussion on happiness in $D e$ Beata Vita. She closes this dialogue with an important qualification. She admits that the happy life consists of knowing perfectly and precisely $\mathrm{Him}$, and she indicates to the reader that this is to be achieved by being led by the virtues of faith, hope and love. ${ }^{32}$ What this means is that the happy life is not necessarily a commodity acquired by the intellect alone. Monica's insight tempers this purely intellectualist view of happiness. The happy life is not merely an idea had in the mind efficacious in producing measure and its corollary happiness. Her comment places the happy life squarely within a Christian context. The happy life must include knowing and pursuing God through faith, hope, and love. Therefore, Augustine's discussion of happiness concludes that eudaemonia must be understood within the boundaries of God and a life which seeks God. ${ }^{33}$

\section{Section IV.b: Development in the Wisdom of Faith, Hope, and Love-Climbing De Doctrina's Ladder of Love}

The exercising and effect of this life of Christian virtue is nowhere more obviously illustrated than in Augustine's, De Doctrina Christiana. In Book II of De Doctrina, Augustine employs, silently, the metaphor he introduces in De Libero Arbitrio approximately thirty years earlier. In this latter text, Augustine concludes that the acquisition of the happy life is a slow process akin to walking a road or highway. But, in the former text, Augustine utilizes this previous metaphor and maps out a progressive spiritual road towards what can be considered the human good-eudaemonia. This dynamic movement of the soul, through various stages towards happiness, is what I will term, "via spiritus." ${ }^{4+4}$ And this pursuit, Augustine admits in this text, is a matter of seven successive and advancing stages characterizing the person's spiritual evolution towards their final good. 
The initial step in this process is one of humble, respectful recognition of God's reality and presence. The return to God starts with a fear of God, prompting persons to become acutely aware of their own mortality and eventual future judgment. This fear leads to the second rung in the evolution of via spiritus. Out of this fear is generated the ability to "grow modest with piety, and not contradict the divine scripture, whether we have understood it when it lashes our vices, or whether we have not understood it, as though we could have better ideas and make better rules ourselves." 35 The virtue of piety, for Augustine, begins to introduce a Christian novice to genuine knowledge, a knowledge recognized as the right precepts of life: love of God first and foremost, and your neighbor as yourself. Furthermore, Augustine asserts that this knowledge is tinged with the hope of victory over self and the resultant drawing closer to God thereby. He writes, "this knowledge, filled with hope, leads one to bewail oneself, not to vaunt oneself; and in this frame of mind one begs with assiduous prayer for the consolation of divine help, to prevent one from being crushed with despair." ${ }^{36}$

The fourth stage is defined by a single virtuous desire, the Augustinian motif returns and there is an exclusive desire for justice. Augustine describes the spiritual temperament of this fourth stage as one which, by way of fortitude and courage, aims at satisfying the craving for justice. The end result of this craving is a struggle with the will, and the desired aim of this fourth stage is the elimination of wrong loves. Next, the fifth stage is the result of the fourth stage's success. Only after the wrong loves have been mastered and effaced, can the person begin to develop the appropriate loves of the fifth stage. And so the fourth stage seeks to eliminate wrong loves, while the fifth stage seeks to re-habitualize the person in the way of right love - love of God and neighbor as self. In addition, this perfected love further promotes the hope and unimpaired powers ${ }^{37}$ that leads to the sixth stage: the stage, "at which you purge and clean those eyes with which God can be seen, insofar as he can by those who die to this world, insofar as they can." 38 This stage cleans the heart and mind so that the person is prepared to usher in the final stage: the stage available to those who are single-minded and pure in heart. ${ }^{39}$ These persons Augustine describes as climbing up to wisdom, the wisdom of peace and tranquillity. ${ }^{40}$ 
In reality, the virtues of faith, hope, and love spoken of overtly in the Cassiciacum dialogue of his early years, De Beta Vita, are covertly the primary constituents of De Doctrina's via spiritus. De Doctrina catalogues the Christian virtues in their dynamic, existential playing out within concrete human experience. This is evident when one examines the early stages of Augustine's evolutionary spiritual scale. This examination brings to light the fact that fear of God, piety, submission to the knowledge of God and a life devoted to neighbor as self are all embedded in the fundamentals of Augustinian faith experience. Without faith, there is no God to fear, submit to, or a revealed scripture which expresses the few, but important, truths inaccessible to the now crippled, unaided human intellect. Moreover, in these early stages hope is augmented as one climbs further up the via spiritus. Neither is the final Christian virtue to be forgotten in Augustine's spiritual ascent. In fact, the fourth, fifth, sixth, and seventh stages of via spiritus are primarily organized around this idea of love. In these later stages the idea of concrete, Christian, existential love is being shaped and worked. The self's wrong loves, with time and God's grace, are purged. This cleansing of love is not without its purpose voiced in the fourth stage as the person's struggle for justice. In De Doctrina, this struggle culminates in a vision of Christian wisdom as love.

Sapientia (wisdom) is understood by Augustine on a series of different levels. There are those interpretations already discussed in De Beata Vita such as fullness of satisfaction, or the true measure between excess and deficiency. The young Augustine penning this early dialogue presumes that wisdom must be reasoned out as the authentic satisfaction of desire by way of an actively progressive life in faith, hope and love. And this wisdom attained in God is true wisdom. The via spiritus of De Doctrina subsumes all of these various interpretations of wisdom found in the early dialogue, but also adds others, namely, the themes of justice and love, found repeatedly throughout much of the more mature Augustinian corpus.

In De Civitas Dei, as addressed earlier in this paper, justice is a matter of giving each its appropriate due, and, in like manner, Augustine's process of spiritual reawakening requires learning to 
give each of the various objects of love their appropriate due. Justice demands that the better be preferred to the worse, the eternal Trinity to the objects of the temporal world, brother and sister loved in God and as an equal to yourself. The final stage in the spiritual life includes first successfully mastering the problems of the earlier stages. Accordingly, the seventh and last stage requires that one first struggle with the craving for justice, a desire demanding that one learn to love ordinately. De Doctrina asserts that in the way of the spirit, there can be no wisdom of the seventh stage without there first being the struggle of the earlier stages for justice. To be wise is to love justly, giving each object in life its appropriate due.

But the grace-inspired life of faith, hope, and love seems oriented towards yet another way of interpreting wisdom that I will term, "sapientia caritatis"-1!. Augustine's via spivitus concludes that the final, highest stage of the spiritual life is that stage in which the mind and heart have been purified in love and actively hosts the reciprocally infectious love of God. As a result, in De Doctrina, sapientia caritatis appears to be the terminus or aim of via spiritus, and as such is the final human condition described by Augustine as enjoyment in peace and tranquillity. Eudaemonia, the good for humanity, happiness, Augustine interprets in other texts, again such as De Civitas Dei, as precisely a matter of this very same peace and tranquillity. And so Augustine's way of the spirit describes the powerful, grace-inspired movement through a life of faith, hope, and love towards sapientia caritatis: a reordering of the self, in love, so as to cause a re-spiritualization of self and world. Sapientia caritatis, thus, gives rise to a symbiosis of individual entities, a harmony of what was before disparate parts within the infusing love of God. Within this love, the person more fully and perfectly integrates, and in like manner the community of persons more fully integrates; they become a unity of beings within God's presence of love, all of their concerns equal, all their lives unified in the uniform love of God and each other in God. Peace and tranquillity in unanimity and reintegration is established. The human good is achieved and all persons find health by way of this love.

But Augustine does not arrive at this vision alone. Thus, this Augustinian vision of love develops out of St. Paul's exhortation 
in $I^{\text {st }}$ Corinthians, Chapter 13. In brief, in this chapter, Paul considers the primacy of love. Language and the most eloquent of words, are mere nonsensical sounds if not uttered within the presence of God as Love. Knowledge, another human good, is mere foolishness, if Divine Love is not working in the background of the mind at labor. Faith, likewise, is paralyzed and empty if not quickened by Sacred Love. And in the end, for Paul, there seems to be only three significant constituents to reality: to believe in faith, to long in hope, and to care in love. But in time, like all else, faith and hope fade away. Ultimately, faith is understood, hope is realized, and so it is love alone that can be said to endure.

Augustine's via spiritus emphasizes this same Pauline vision. To be sure, faith and hope are most necessary but only as cornerstones for a genuine human happiness understood as an intoxicating love of God permeating the soul and life of the person, creating a salubrious unity in the presence of multiplicity. For Augustine, this love is the human good; it is the health and happiness of the human soul; it is eudaemonia. In unison, these three graceinspired Christian virtues are the most medicinal of all virtues. They act so as to guide the person towards a eudaemonia embodying the salutary, loving peace that comes of a just order, an order of love rooted in faith and carrying a sole hope in both the order's love and the Orderer which is love.

\section{Section IV.c: The Augustinian Account of Eudaemonia and Wisdom and their Relationship to Nussbaum's Medical Moral Paradigm}

As addressed earlier, Nussbaum believes that all medical moral philosophies contain certain unique elements or features distinguishing them from other types of moral philosophies. She argues that medical moral philosophies invariably aim at happiness and the human good eudaemonia-understood as the health of the human soul. As explained in this section, Augustine's ethic likewise aims at the human good since it is elldaemonistic, and, as such, happiness is its aim.

In Augustine's ethic, eudaemonia can easily be considered the standard of health and sapientia caritatis can be considered 
synonymous with eudaemonia. ${ }^{42}$ Given that this is so, in Augustine's ethic, the flourishing life might be understood as the life of faith, hope, and a most perfect, just love.

It can be concluded that the arguments concerning happiness and the well-lived life are practical ${ }^{43}$ in nature. Simply, these eudaemonistic views and positions attempt to make the person better. They attempt to produce the health and happiness of the soul in this life and the next. Self improvement entails following the progressive stages of via spiritus towards sapientia caritatis.

Augustine's eudaemonistic ethic can be considered responsive to the deep wishes or needs of people. ${ }^{4+}$ In fact, Augustine's ethic can be considered a prime example of this responsiveness. At its core, Augustine's ethic is above all concerned with human needs, desires, and aspirations. The wisdom of love, as a goal of action, is that perfecting idea and power which prioritizes, organizes, measures, and orders the various needs, desires, loves, and longings. Seen from this point of view, the very essence of his ethic, then, includes the arrangement of profound individual wishes, needs and longings.

The arguments of Augustine are responsive to the particular case. ${ }^{\text {t5 }}$ Augustine's eudaemonistic ethic is an ethic of the particular individual and their loves, and so his ethic's aim is to reach out to the individual and their particular situation. This responsiveness includes a reorganization of the complete life of the individual and is achieved by the daily reorganization of the particular individuals loves, beliefs and choices. Augustine's ethic attempts to achieve his most important objective: the health and salvation of the particular individual soul in this life and the next.

\section{Section V: The Augustinian Account of Grace and its Rela- tionship to Nussbaum's Medical Moral Paradigm}

For Augustine, God is the source of all goodness. So in Augustine's world view, all good things flow from the perfect goodness of God. In addition, all of the various goods which God brings about are freely given as gratuitous acts of the infinite generosity of the infinitely good God. In this sense, even the goodness of the universe, its beings and unique existence, is attributable to the freely 
chosen, creative act of God. The grace of God, then, can be considered so all-pervasive that even the created order, along with all that is within it, can be viewed as a manifestation of His gracious gift. Gilson comments:

Since God is the sovereign good, He is self sufficient; hence, all his gifts are freely given and gratuitously, and in this sense every one of his works is a grace. Man did not have to merit existence, because to merit it he would first have had to exist. Now although he did not exist, he was made, and made, not only like a stone or animal, but to his creator's image. In this improper sense, even nature itself must be a grace, but a universal grace so to speak, and common to everything. ${ }^{\text {th }}$

Where, then, did evil come from in this world that was created by God? In order to explain evil in God's perfectly created order, Augustine insists that through one willful act of disobedience, by a pair of beings who were made good, but not perfectly good, evil came into the world. The first man and woman, Adam and Eve, were beings who, because of their nature, were susceptible to corruption. ${ }^{47}$ They were liable to be corrupted and eventually were corrupted by their own free choice to disobey the commandment of God, subsequently, distancing themselves from God. Adam and Eve's baneful, pernicious choice introduced evil into an innocent world, and, according to Augustine, the original sin of this first man and woman corrupted all. ${ }^{48}$ Through this first sin, humanity was forever distanced from God, human beings were oriented away from their good and towards its opposite: error, concupiscence and death. With the fall, humanity relinquished the power to free itself from inordinate and wrongly ordered loves, thereby losing its ability to love properly and acquired a misguided orientation of desire. In short, after the fall, humans became predisposed to loving the wrong things in the wrong way, or the right things wrongly. However, they did so freely. ${ }^{49}$ For Augustine, human beings freely chose to distance themselves from God, habitually reoriented their loves away from the eternal, and justly 
deserve the rightful fruits of this choice: sin, misery, error, and death.

The fall initiated a tendency towards a wrong-turning, and Augustine argues that now grace counters this condition. Grace is that gift from God which corrects the fallen nature of humankind because it strengthens a crippled human nature and reorients its will and loves. Likewise, grace prompts the virtues of faith, hope, love, wisdom, and justice. Now grace reestablishes the liberty of the human person; it liberates humans from their ill-directed loves when it strengthens humans' will and ability to redirect themselves towards the eternal. Grace allows persons to become faithful, hopeful, loving, wise, and just when it allows persons to recognize God's will and God's just law and act upon them. ${ }^{50}$

Grace produces the good for humankind in two very different ways. First, grace, as a gratuitous act of God's self giving, is behind the created order. It is by means of the grace of God that the world exists in the unique, good way that it does. The world is good and it is a gift from God that the world is created as such.

After the fall though, grace plays a new, different role in human health and happiness. Grace, Augustine credits for the ability to believe in God faithfully, ${ }^{51}$ and it is out of this faith that both hope and love flow. To have grace-inspired faith is to have the prerequisite for the other saving virtues. Moreover, Augustine believes that these three simple virtues-faith, hope, and lovenow have the most salutary of effects for the human person.

And so for Augustine, there does appear to be a method or procedure which produces happiness, peace, and joy for the human soul. However, this procedure or method is primarily spiritual. This method is what Augustine calls "grace." 52

\section{Section VI: Augustine's Confessiones-Picturing De Doctrina's Progressive Life of Faith, Hope, and Love-A Case in Point of an Exemplum}

Augustine's Confessiones can be interpreted in a variety of ways. But when interpreted within the context of his other writings, especially De Doctrina, this extended prayer to God might be easily seen and understood as the story of a diseased soul pro- 
curing health by way of progressive advancement in faith, hope, and love.

First, regarding the theme of disease, the first nine books of the Confessiones catalogue Augustine's attempts to relieve himself of his wrong loves, these loves being functions of the misapplied individual, unique powers given to the man. Augustine's mind was strong, his rhetorical powers of persuasion titanic, but by his own admission, these talents of mind and tongue, he perverted, devoting them to a life pursuing vainglory, reputation, power, convenience, and lust. This mis-direction of his time and aptitudes, he recalls, brought about his living death and were not without their adverse effects. He acquired envied teaching positions, money, ease of life, children and, in later life, a wife of reputation, but none of these could satisfy a longing within. Happiness eluded him in spite of these temporal goods in abundance, and so in his early life, sorrow and malaise are his most constant possessions. Describing this condition he later attributes to his sinfulness, he writes:

In this lay my sin, that not in him was I seeking pleasure, distinctions and truth, but in myself and the rest of his creatures, and so I fell headlong into pains, confusions and errors. ${ }^{53}$

And nowhere is the unhealthy condition of his soul portrayed with as much clarity as in the account of the beggar in Book VI. By way of this experience, Augustine represents the shallow nature of his life's intention, side by side the emptiness in mind and heart. In Book VI, Augustine sets out to describe a seemingly everyday, mundane occurrence. He explains that one day, while passing through a district in Milan, he happens upon a common beggar, described as intoxicated and so joyful. This chance meeting, more strongly than ever, forces Augustine to question the direction of his life and the thrust of his life's ambitions. This stimulates an examination of his life up to this point. On the one hand, he understands that he might easily be considered successful in the eyes of others: After all, he is a teacher of rhetoric in an important city like Milan; he is a man of letters, erudite, powerful in his 
persuasion, and respected. Yet, in spite of these accomplishments, Augustine realizes that, in fact, he is to be pitied. The drunken beggar compels Augustine to confront his grief. The childhood beatings meant to motivate more assiduous study habits (but probably only produced a disdain for learning Greek), the struggle of his later formal education in Carthage, the financial burden his father bore for his education, all of these labors, in addition to others, Augustine concluded produced nothing but anguish and sorrow. Hence, in his own mind, he became dejected, humbled by a common drunk begging for his happiness. In spite of all of his learning and reputation, the drunken beggar had acquired what was eluding him. The beggar was drunk, but happy, and Augustine was respected and learned, but hollow.

His joy was no true joy, to be sure, but what I was seeking in my ambition was a joy far more unreal; and he was undeniably happy while I was full of foreboding; he was carefree, I apprehensive..$^{54}$

Admittedly then, Augustine's condition was despondent, devoid of what he most longed for. In Book VIII he admits that this condition was gradually ameliorated, starting with the famous conversion experience in the garden. Contiguously prior to this scene though, Augustine describes his painful life amidst the bonds of spiritual death. Moreover, he expresses ideas important to understanding this event as a linguistic picturing of De Doctrina's via spiritus.

In the passages just prior to the conversion scene, Augustine alludes to his experience of God at this point in his life. The God pictured is an angry God, vengeful in nature and exacting a heavy toll for his misdeeds. His God is a deity to be feared, and Augustine respects this God. Also there is relayed to the readers a tenor similar to one that might be felt at a final judgment. Augustine, viscerally, feels himself as sinful in the presence of this stern God, and so calls out for an imperative mercy.

O Lord, how long? How long? Will you be angry forever? Do not remember our age old sins." For 
by these I was conscious of being held prisoner. I uttered cries of misery. ${ }^{55}$

And so just prior to the scene of conversion, Augustine introduces themes consisting of: fear of God, the judgement before God, and memory of one's mortality (spiritual death). The beginning steps of De Doctrina's ladder of love have been ascended.

In his introduction to the conversion scene, Augustine starts by way of describing the event through which God responded to his need. He laments his sins, along with his impotence in the face of them.

I went on talking like this and weeping in the intense bitterness of my broken heart. Suddenly I heard a voice of some boy or girl, I do not know singing over and over again, 'Pick up and read, pick it up and read. ${ }^{56}$

Augustine believed this to be no ordinary voice. To him, this was the voice of the loving God providentially at work within his life. This voice beckoned Augustine to pick up the Pauline Letters where he read:

Not in dissipation and drunkenness, nor in debauchery and lewdness, nor in arguing and jealousy; but put on the Lord Jesus Christ, and make no provision for the flesh or the gratification of your desires. ${ }^{57}$

This passage gave Augustine a renewed sense of hope. The voice of the child was the utterance of God reacting to his plea for help in love. God displayed his mercy, a mercy which lead to the hope of resisting his weak will. Following this experience, Augustine sees himself anew as Monica's dream had foretold. He was finally "standing on the rule of faith" 58 resulting in a surge of hope and redirection of love. This newly infused hope was a hope in the ability to overcome himself, thereby purifying his wrong love and learning to love justly all things. Still later in Book IX, Augustine 
describes the effects of his rejuvenated and unimpaired spirit. Soon, after this encounter of grace, he hints at an empowered love of others and self., ${ }^{59}$

Augustine's conversion produced a more dominant love of God portrayed as an increased love of others, along with its subsequent ability to unite persons. Alone and looking out over a garden, Monica and Augustine join in mystical experience.

...we lifted ourselves in longing yet more ardent toward That Which Is, and step by step, traversed all bodily creatures and heaven itself, whence sun, and moon and stars shed their light upon the earth. Higher still we mounted by inward thought and wondering discourse on your works, and we arrived at the summit of our own minds; and this too we transcended, to touch that land of never failing plenty where you pasture Israel for ever with the food of truth. ${ }^{(x)}$

For Augustine, this ecstatic encounter is a precursor to the perfect unification to come of all persons in the love of God, but yet, this passage illustrates something more, the effects of God's love in this world as well. Simply, this passage pictures two persons fusing in love, a love that seems to reach beyond their distinct individuality. Consequently, the ecstatic experience of Augustine and Monica portrays sapientia caritatis, unity in love.

But the love of God also is shown to have a therapeutic effect in the life of Augustine. In the chronology of his life, Augustine writes that this conversion experience produced in him the goods absent in his earlier life. The beggar episode made clear to Augustine the facile nature of his early life. His younger years were spent pursuing shallow ambitions and the result of this was a persistent dissatisfaction. Something was missing. Augustine, post conversion, is able to brand himself more peaceful and happy. Something has been found. The life of Christian virtue allowed Augustine to advance down the path of eudaemonistic, perfect love, and this was therapeutic for him. Speaking in the language of sin, the post conversion Augustine writes of this lately discovered peace and contentment: 
My mind was free at last from the gnawing need to seek advancement and riches, to welter in filth and scratch my itching lust. ${ }^{\text {(1) }}$

After his conversion, Augustine portrays himself, due to the redirection of his loves and life, as finding more peace and happiness through liberation from the diseased bonds of sin and vice. By ascending the ladder of love through faith and hope, Augustine is more fully integrated in himself and unified with others. By way of development in faith and hope, he has a new insight into the wisdom of love.

In the Confessiones, Augustine paints a picture of both a diseased, anxious, dissatisfied, life, but also a more healthy, peaceful, happy life. Augustine does not merely express arguments and ideas in this text, but testifies to two very different people and livesthe happy satisfied life of Christian virtue, along with its opposite. It is not by an act of caprice that Augustine chose to express the ideas inherent in his ethic according to this autobiographical method. Instead, Augustine chose to express himself and his system in this way, since this medium, distinctively, expressed his system most effectively. And this type of expression, by Nussbaum's own account, is a staple of the medical moral paradigm.

\section{Section VI: Grace, Its Reconciliation with the Autonomous Human Good, and the Otherworldly Dimension of the Life of Eudaemonia-the Problems of Compatibility Explained and Resolved}

At this point, I think a set of obvious problems comes to light that can now finally be addressed. Concerning the role of grace in . Augustine's ethic, I think it may appear that grace looks to be locus of the human good. After all, since the fall, grace is required to merely believe, while belief is a prerequisite for taking God's just law seriously and attempting to develop and perfect the law of love in the course of a human life. Furthermore, it is by way of perfecting the law of love that human happiness and well being is produced. Therefore, it might be concluded that God's grace is 
that which promotes health and happiness, rather than the nature of the being itself.

All of this appears true, but a more detailed examination of the problem shows that Augustine's ethic presupposes, too, that humanity, by a gracious act of God, was originally constructed according to the good. Augustine's ontology argues that the human good was originally part of ourselves, however we chose to distance ourselves from this good and must, henceforth, pay the penalty. Originally, by way of the gratuitous gift of God's creation, God intended that humans provide themselves with their own well being. In fact, according to Augustinian ontology, He gave human beings the tools necessary to achieve their good by weaving their good into the natural fabric of their being.

Thus, I believe Nussbaum fails to interpret Augustine both as Christian devotee, exclusively devoted to revealed scripture, but also as a philosopher/theologian concerned with ontological questions of being. Given this, she appears unable to sufficiently recognize the complexity of Augustine's religious vision, and hence understand how, within his system, grace might be reconciled with an independent human good.

Bourke's views on Augustine's ontology helps to make sense of this reconciliation. Bourke contends that the locus of the human good is yet more subtle. The good for human beings, looked at from the biblical point of view solely, as Nussbaum does, concludes rightly that the locus of the human good is to be found in an overly simplistic view of grace, and also the biblical injunctions of an all powerful, commanding Other. But, as Bourke would have us believe, from the more muanced outlook of Augustine's Christian ontology, the locus of the human good re-adjusts its origin, finding itself nestled securely within the ontological fabric of the created human being and its experience. Regarding grace and its relationship to the human good, Nussbaum, then, fails to sufficiently and comprehensively examine Augustine the Christian intellectual. Considering Augustine's views in their totality, Nussbaum would have found, I believe, that according to the Augustinian Christian ethic, and its supportive ontological structure, the good for humankind originates in God's grace, but also human being. God's will and God's gracious gift are behind the construction of the human being, but the human being along with 
its coterminous good. In a word, ontologically speaking, for Augustine, the human good might be considered human innocence, and human innocence is real.

A second problem might include the "otherworldly" dimension to Augustinian eudaemonia. After all, for Augustine, perfect integration and unity is an actualized condition only outside of time and in an eternal after life. The objection might be made that Augustinian eudaemonia lacks concreteness since the soul can never find health and happiness in the world in which we all now find ourselves. The Augustinian ethic, however, might respond to this objection by claiming that in regard to its "concrete" character, its account of eudaemonia is no different than any other medical moral philosophy. In reality all medical moral philosophies work within the same concrete world, and because of the nature of this world, the health of the human soul is always only quantifiably established, meaning, that for all medical moral philosophies, eudaemonia is never perfectly realized, and if realized, is so only in degrees. Augustine's ethic is no different in this regard.

This temporal world often presents itself as threatening and hostile. Consider again the very aim of philosophizing in the Hellenistic world given by Nussbaum herself. It was the urgent need for health. Remembering that you only need what is lacking, by her own admission, what was lacking in the concrete lives of persons of that period was human health. The world in that period, like all others, testifies to a single, recurring fact: our human condition is difficult, potentially riddled with adversities and problems. In short, the world is not clean, and never has been. Furthermore, this view seems a given to all medical moral philosophies. This concrete world allows the human being only degrees of health, thus, the aim of the medical moral philosophy is quantified healing. In other words, given the state of the world-imperfect, temporal and in flux-circumstances change, while these changes at times do not promote our well being. The human good can only be acquired to some degree, as our health today will be disturbed tomorrow, or the next day, etc.

In further support of this claim, consider one of Nussbaum's "legitimate" medical moral philosophies-the Stoic. The Stoic ethic reconciled the hostile nature of the world, on the one hand, 
and their vision of goodness, on the other, by prescribing suicide in certain situations, even for the "battle hardened" Stoic sage. The most ethically advanced then, that person most healed by the therapeutic philosophy, had to confront the idea of eudaemonia as measured. Perfect and absolute health was beyond the scope of the potentiality of this world. This seems a fact to the Stoic ethic, and what's more, the Stoic ethic, itself, as medicinal, was a response to this fact. The world was potentially an antagonistic place and tomorrow fate may prove too much for reason to combat. The Stoic sage could find a measure of happiness through submission to reason, but because of the nature of the world, this health and happiness was tenuous. According to the breezes of fate, health could be eliminated at any moment and often was. Suicide turns out to be a recognition that pain was a potential, constant reality impinging on health. Perfect health was impossible, and eudaemonia was a matter of degree then even for the sage.

The consequent of this is the view that quantifiably, in a medical moral philosophy, one might always have more and less health. Like the Stoic ethic, the Augustinian assumes the world as is and makes no grand offers. The world is a sometimes dangerous, sometimes beautiful place, full of pain potentially, and joy potentially, but consistently, the world is full of God's presence and love. This ethic does believe that, in this concrete world, more health is acquired through approximating the love of God by way of Christian virtue. God is present in the world before our eyes, and his ethic promotes a necessary responsiveness to this concrete world, not only the next world hoped for. Indeed, the Augustinian ethic presumes that our ability to perceive God's love will grow more intense in an after life, but this belief does not preclude the concern the ethic gives to this world and its projects. God is present concretely. The beauty, truth, and goodness of this world reassures Augustine of this reality. His ethic, then, entails straddling the Civitas Dei, but also the civitas mundi. A foot must be kept in each. This ethic's vision appreciates the person as ideally advancing through this good but imperfect world, more often than not, gaining a measure of peace and joy as one advances in caritas, but likewise keeping in sight the hope of God's eternal vision. The via spiritus and Augustine's Confessiones illustrate this eudaemonistic movement of the soul through the ephemeral life. True, this ethic 
concludes that the eternal life to come will perfectly restore our happy innocence, but even in this temporal world, the diseases and pains which are so real can, to some extent, be assuaged. In measure only, health can be established here and now, but a measured health and happiness is a real health and happiness, even if not perfectly realized. For Augustine then, eudaemonia is concrete as well as otherworldly since God's love is omnipresent, and our ability to perceive and cleave to this love is a matter of our will.

\section{Conclusion}

Martha Nussbaum claims that the Augustinian ethic cannot be considered medical because it fails to arise out of human being, its needs, desires, and aspirations. This is her principal problem with this ethic and the fundamental reason why she precludes this ethic from the category of medical moral. In retrospect, this paper argued that, according to the Augustinian ethic, God, the whole of His good created order, and the love inherent in this order, is precisely the proper end of the various needs, desires, and aspirations universally given within individual human experience. Augustine's ethic implicitly draws this conclusion: the health and happiness of the human soul requires a reunification of the self with its natural coterminous good. This reunification, though, can only be accomplished when a right relationship has been formed between the image of Love within and the Perfect Love without. In short, this reunification requires reuniting the loves of the inner self with the extraneous God, His just order, creation and the infinitely rich love given within all of these. In a sense, this reunification involves, simultaneously, a self-forgetting, but also a self-recalling. For Augustine, this reunification entails a forgetting of the present self, its errant beliefs, loves, and passions, and a remembering of one's original self, that self which was once healthy, happy, peaceful, and joyful since it loved as it ought. Now though, God must assist humans in their endeavor to both forget and remember, and He does this. God showers humankind with the greatest of all possible gifts-the power to love, not as we do, but as is best. For Augustine, by means of His grace, God does so will this, His greatest desire: that we all simply forget ourselves and return home. And if only we would share in God's greatest desire, then what He and 
we most want would come to pass. We would find again our human innocence lost.

\section{Works Cited}

Saint Augustine. City of God. Translated by Gerald G. Walsh, Demetrius

B. Zema, Grace Monahan, Daniel J. Honan. New York: Doubleday, 1958.

Saint Augustine. The Confessions. Translated by Maria Boulding. New York: New City Press, 1997.

Saint Augustine. The Enchiridion on Faith, Hope, and Love. Edited By Henry Paolucci. Washington D.C.: Gateway, 1991.

Saint Augustine. Of True Religion. Translated by J.H.S. Burleigh. Chicago: Henry Regnery Company, 1966.

Saint Augustine. On Free Choice of the Will. Translated by Anna S.

Benjamin and L.H. Hackstaff. New York: Macmillan Publishing, 1964.

Saint Augustine. "On The Happy Life." In Augustine of Hippo: Selected Writings. Translated by Mary Clark. New York: Paulist Press, 1984. Saint Augustine. Sermons. Translated by Edmund Hill. New York: New City Press, 1992.

Saint Augustine. Teaching Christianity: De Doctrina Christiana. Translated by Edmund Hill. New York: New City Press, 1997.

Saint Augustine. The Trinity. Translated by Edmund Hill. New York: New City Press, 1991.

Bourke, Vernon. Alıgustine's View of Reality. Philadelphia: Villanova Press, 1964.

Deleuze, Gilles. Nietzsche and Philosophy. Translated by Hugh

Tomlinson. New York: Columbia University Press, 1983.

Gilson, Etienne. The Christian Philosophy of Saint Augustine. Translated by L.E.M. Lynch. New York: Random House, 1960.

Holtzen, Thomas L. The Therapuetic Nature of Grace in St. Augustine's De Gratia Libero Arbitrio. in Augustinian Studies: Volume 31, number 1, 2000. Ppg 92-115.

Mallard, William. Language and Love: Introducing Augustine's Religious Thought Through the Confessions Story. Pennsylvania State University Press: University Park, Pennsylvania, 1994.

Nussbaum, Martha C. The Therapy of Desire: Theory and Practice in Hellenistic Ethics. Princeton: Princeton University Press, 1996.

Scott, T. Kermit. Augustine: His Thought in Context. New York: Paulist Press, 1995. 


\section{Notes}

1. Martha Nussbaum, The Therapy of Desire: Theory and Practice in Hellenistic Ethics. Princeton: Princeton University Press, 1994. Pg. 15. Again, this quote alludes to the idea that in the Hellenistic period philosophy's task was to respond to "the urgency of human suffering." Philosophy's function, then, was medicinal; it cured the soul through realizing and living out another goal of philosophizing-eudaemonia or human flourishing.

2. Martha Nussbaum. The Therapy of Desire. Ppg. 21-22. Nussbaum claims, "We do not in fact look 'out there' for ethical truth; it is in and of our human lives. As in the case of health, what we are looking for is something that we are trying to bring about in human life, something essentially practical, whose point is living and living well. This something is unlikely to be grasped if we detach ourselves completely from our wishes and needs and aims. It must be found, if at all, from within ourselves and one another, as what answers the deepest aspirations we have for ourselves and one another. And it is justified as correct by the fact that it does so answer."

3. Martha Nussbaum, The Therapy of Desire. Ppg. 17-25. Nussbaum argues that Plato's conception of ethics cannot be considered medical because it is essentially divorced from the domain of human life. Medical ethics attempts to treat the human soul, and as such it must find its foundation in the human being, its needs, aspirations, and life. With medical ethics, the idea is that you treat the patient by examining the patient, not some Form. So both the problem and cure come from the patient and their life. According to Plato's conception, Nussbaum argues, ethical truth first begins by way of investigation of an immaterial and unchanging Form or Archetype. According to Plato's vision, the ethical norms which guide human life do not arise from human life, but instead, a perfect and unchanging Idea. The divorce between ethics and the human being, Nussbaum contends, leads to the real possibility that, "The best life may turn out to be a life that none of us could attain, or even that none of us could grasp or envisage. Or, again, it might turn out to be a life that is so out of line with all actual human ways of life, and with all actual human desires, that human beings as they are would find it repugnant, or base, or so boring or impoverished that they would die rather than live it." As far as the conception of traditional social belief is concerned, Nussbaum believes that this view of ethics is not medical but simply mimetic. In other words, this view, she argues, understands ethics not as something which fosters the health of the person, but merely as 
a series of beliefs which can be traced back to the society at large. Ethical beliefs have no real value outside of social utility and their basis too is grounded in the beliefs of society at large. The ethical beliefs of individuals, then, are merely the parroting or mimicking of communal beliefs.

4. Martha Nussbaum. The Therapy of Desire. Pg. 18.

5. Martha Nussbaum. The Therapy of Desire. Pg. 18.

6. Martha Nussbaum. The Therapy of Desire. Pg. 19.

7. Martha Nussbaum. The Therapy of Desire. Pg. 19.

8. Martha Nussbaum. The Therapy of Desire. Pg. 26. Nussbaum insists that any medical moral philosophy is concerned with, "people whose beliefs, desires, and preferences are themselves the problem." She also writes that, "philosophy understood along medical lines deals with both beliefs and emotions or passions." (Pg. 37) All medical moral philosophies are required to alter erroneous beliefs, efface irrational fears and anxieties, eliminate debilitating hatreds and angers, and finally realign harmful loves, desires, longings and wants.

9. I call these "therapeutic tools" because they contribute to happiness and the health of the human soul. They are fundamental means towards this end since before one can attain happiness and health one must be able to diagnose "disease", have a standard of "health" which acts as the ideal to be attained, and have some idea in mind as to the procedure to use which can bring one to the "healthy" condition. These ideas, then, are "tools" because each, in its own way, is critical for the construction of a healthy, happy soul.

10. Martha Nussbaum. The Therapy of Desire. Ppg. 28-29.

11. Martha Nussbaum. The Therapy of Desire. Pg. 46.

12. Martha Nussbaum. The Therapy of Desire. Pg. 339. Other examples of exemplum include the letters of Seneca. In these letters, Seneca expresses his thoughts in an imaginary conversation with a friend. The conversation includes highly personal testimony as to his faults and misgivings. He teaches about Stoicism while relating to his audience through his own humility. It is my impression that Nussbaum believes that the Stoics developed this didactic tool to its fullest extent.

13. Vernon Bourke. Augustine's View of Reality. Villanova Press, 1964. Pg. 18.

14. Vernon Bourke. Augustine's View of Reality. Pg. 18. Bourke argues that in the Literal Commentary on Genesis, Augustine professes that the universe was created by God according to an order which includes measure, number, and weight. Measure, number, and weight are considered by Augustine the primary determinants of the world.

15. Vernon Bourke. Augustine's View of Reality. Ppg. 20-21. 
16. Vernon Bourke. Augustine's View of Reality. Pg. 22. The idea of eternal goodness and it's abiding existence within the created human is one of the fundamental points expressed within Augustine's ontology. As this paper will argue, the human good inherent in the ontological fabric of the human person provides for human eudaemonia, while this eudaemonia is salutary. There is a correlation then, in Augustine's ethic, between the abiding goodness of existence and a health and happiness which therefrom flows. Nietzsche's philosophy gives comment regarding the idea of this association. In short, I believe his philosophy rejects its existence. Gilles Deleuze's commentary on Nietzsche, Nietzsche and Philosophy, offers the thought, that for Nietzsche, "the suffering of life needs to be justified, that is to say redeemed from suffering and contradiction." (Pg.11) Moreover, a response to this problem of human suffering and contradiction is found in an "Apollonian" attitude to life. "He (Apollo) constructs the appearance of appearance, the beautiful appearance, the dream or the plastic image and is thus freed from suffering: 'Apollo overcomes the suffering of the individual by the radiant glorification of the eternity of phenomenon', he obliterates pain" (Pg. 11) Furthermore, Augustine's religious and ontological vision would probably be considered by Nietzsche as in accord with the "ascetic ideal", an ideal which produces "ressentiment and bad conscience", and which "permits the deprecation of life and all that is active within it." (Pg. 145) In addition, the ascetic ideal includes, "the fiction of a world beyond." (Pg. 145) The "world beyond" might be considered the eternal and abiding world. The human good conceived, whether it be Nussbaum's, the Stoic, the Aristotelian, the Epicurean, or the Augustinian, is somehow inextricably bound up with that which remains firm, and as such deserves recognition as a more stable, firm existence. This conception of stable, abiding or universal existence Nietzsche would find "Apollonian" in nature. Thus, as a result, I believe Nietzsche would regard the medical moral philosophy project as suspect, in any of its forms, and, furthermore, a fiction which makes life livable, but at the price of authenticity towards life. However, responding to Nietzsche's polemic would require another complete project, and that is outside of the constraints of this paper and its thesis.

17. Saint Augustine. De Civitas Dei, Corpus Christianortum, series latina, volumes 47-48. Pg. 260. "Non tamen amplius quam duo quaedam genera humanae societatis existerent, quas civitates duas secundum scripturas nostras merito appellare possemus. Una quippe est hominum secundum carnem, altera secundum spiritum vivere in sui cuiusque generis pace volentium et, cum id quod expetunt adsequuntur, in sui cuiusque generis pace viventium." I have followed the translation of Walsh, Zema, 
Monahan, Honan in Saint Augustine: City of God. New York: Doubleday, 1958. Pg. 295.

18. Saint Augustine. De Civitas Dei, Corpus Christianorum, series latina, volumes 47-48. Pg. 404. "Fecerunt itaque civitates duas amores duo, terrenam scilicet amor sui usque ad contemptum Dei, caelestem vero amor Dei usque ad contemptum sui. Denique illa ipsa, haec in Domino gloriatur. Illa enim quaerit ab hominibus gloriam, huic autem Deus conscientiae testis maxima est gloria." I have followed the translation of Walsh, Zema, Monahan, Honan. Pg. 321.

19. Saint Augustine. De Civitas Dei. Corpus Christianorum, series latina, volumes 47-48. Pg. 230 "ne cuiquam sacrificet nisi tantum sibi, et per hoc in omnibus hominibus ad eandem civitatem pertinentibus atque oboedientibus Deo animus etiam corpori atque ratio vitiis ordine legitimo fideliter imperet, ut, quem ad modum iustus unus, ita coetus populusque iustorum vivat ex fide quae operatur per dilectionem, qua homo diligit Deum sicut diligendus est Deus, et proximum sicut semet ipsum." I have followed the translation of Marcus Dods. Ppg. 705-706.

20. Saint Augustine. On Free Choice of the Will. Pg. 61. In De Libero Arbirrio, Augustine comments regarding justice as right order, saying: "Item iuste esse videndum, deteriora melioribus esse subdenda et paria paribus conparanda et propria suis quibusque tribuenda nonne fateberis esse verissimum et tam mihi quam tibi atque omnibus id videntibus praesto esse communiter?" Pg. 65. "Won't you also admit the following to be absolutely true: that we should live justly; that the worse should be subordinate to the better; that equals should be compared with equals and to each should be given his own; and that each of these truths is present for me and all to see in common?" I have followed Benjamin and Hackstaff's English translation. Pg. 113.

21. See part one of Nussbaum's paradigm on page seven.

22. Saint Augustine. On Free Choice of the Will. Augustine comments on sin. He writes, "peccata omnia hoc uno genere contineri, cum quisque avertitur a divinis vereque manentibus et ad mutabilia atque incerta convertitur. Quae quamquam in ordine suo recte locata sint et suam quandam pulchritudinem peragant, perversi tamen animi est et inordinati eis sequendis subici quibus ad nutum suum ducendis potius divino ordine ac iure praelatus est." Pg. 35. "All sins are included under this one class: when someone is turned away from the divine things that are truly everlasting, towards things that change and are uncertain. These things have been rightly placed in their own order and complete the universe through their own peculiar beauty; but nevertheless, it is characteristic of the perverse and disordered spirit to be a slave to the pursuit of the things which 
divine order and law have prescribed should follow its bidding." The translation follows that of Benjamin and Hackstaff. Ppg. 33-34.

23. See part one of Nussbaum's paradigm on page six.

24. See part two of Nussbaum's paradigm on page seven.

25. Saint Augustine. Sermon 150: On the Words of the Acts of the Apostles 17:18-34. trans. by Edmund Hill, New York: New City Press, 1992. Pg. 31. The blessed life is the happy life. For Augustine, philosophers seek to know and live out the blessed life, as do Christians.

26. Saint Augustine. De Beata Vita; volume 32 of Migne's Patrologia Latina. Pg. 72. "Ergo nullo modo dubitamus, si quis beatus esse statuit, id eum sibi comparare debere quod semper manet, nec ulla saeviente fortuna eripi potest. Deum igitur, inquam, qui habet, beatus est." I have followed Mary T. Clark's translation in Augustine of HippoSelected Writings: On the Happy Life, New York: Paulist Press, 1984. Pg. 176. This exploration of the idea of happiness occurs in a dialogue between Augustine, his mother Monica, his brother Navigus, two cousins and a friend Alypius. Interestingly enough to me, it appears that Monica is often times portrayed as the person with the greatest insight to lend to the subject of happiness. In fact, the very method by which it is achieved is articulated by her.

27. Saint Augustine. De Beata Vita; volume 32 of Migne's Patrologia Latina. Ppg. 118-120. "Illud, jam, inquam, sequitur, ut videamus quis non egeat; is enim erit sapiens et beatus. Egestas autem stultitia est, egestatisque nomen: hoc autem verbum sterilitatem quamdam et inopiam solet significare." I have followed Mary Clark's translation in Augustine of Hippo-Selected Writings: On the Happy Life. Ppg. 189193. Augustine, later makes clearer this idea of "measure" or "wisdom." He says, "Modus, inquam, ille ubique servandus est, ubique amandus, si vobis cordi est ad Deum reditus noster." (Pg. 134) As is obvious from this passage, returning to God, then, requires a measured or rightly proportioned satisfaction of desires.

28. Wisdom is proper "modus", while modus had various meanings used in the early medieval period. To the early medieval mind, modus meant measure, size, amount, limit, fashion, way, and manner. In this dialogue, Augustine understands wisdom in the sense of measure, limit and amount. Wisdom is that modus (measure, limit) which is full, that modus (measure, limit, amount) between excess and deficiency. But wisdom as modus can as easily be described, in Augustine's ethic, as right "ordo". To the early medievals, ordo expressed the ideas of rank, order, and arrangement. Hence, Augustine's conception of wisdom as modus might likewise be understood as ordo in two senses. First, wisdom as ordo, includes an ordering of one's desires towards the mean between 
the extremes, but, secondly, wisdom as ordo can likewise be interpreted as limiting the desires within an arranged hierarchy. The Augustinian conception of wisdom is not most fully understood without this sense of ordo because the hierarchy contained in the modus of desire includes limiting, sizing, and measuring the loves, not only according to the mean between the extremes, but also, additionally, according to the better and the worse, the eternal abiding versus the temporal and transitory, according to the ordo of the world. Hence, wisdom and loving wisely necessitates placing the loves in their proper order: the abiding God is to be loved first, while all else, the transitory and temporal, is to be loved for the sake of the abiding God. And if the ordo of love is followed, then a desire will never be satisfied in either extreme, inasmuch as extreme desires are testimony to a love which falls away from the abiding God and are, instead, wrongly oriented. In this way, wisdom's modus of love, simultaneously consists of an ordo of love.

29. Saint Augustine. De Beata Vita; volume 32 of Migne's Patrologia Latina. Ppg. 130-132. "Illa est igitur plena satietas animorum, haec est beata vita, pie perfecteque cognoscere a quo inducaris in veritatem, qua veritate perfruaris, per quid connectaris summo modo." I have followed Mary Clark's translation in Augustine of Hippo-Selected Writings: On the Happy Life. Pg. 193.

30. Roads, I believe, can be considered metaphorically as general directions followed over time. It requires some quantity of time traveled in order to reach the destination which the general direction (the road) aims at. Augustine's idea of happiness, therefore, includes a similar notion. Happiness must include the right direction, but also the right direction traveled over time. Wisdom includes taking the right road, and the right road includes a process of development, over time, in wisdom of mind and heart.

31. Saint Augustine. De Libero Arbitrio; Corpus Scriptorum Ecclesiasticorum Latinorum, volume LXXIV. Ppg. 61-62. "In quantum igitur omnes homines adpetunt vitam beatam, non errant; in quantum autem quisque non eam tenet vitae viam quae ducit ad beatitudinem, cum se fateatur et profiteatur nolle nisi ad beatitudinem pervenire, in tantum errat. Error est enim cum sequitur aliquid quod non ad id ducit quo volumus pervenire. Et quanto magis longe est a veritate, in qua cemitur et tenetur summum bonum. Summo autem bono adsecuto et adepto beatus quisque fit, quod omnes sine controversia volumus. Ut ergo constat nos beatos esse velle, ita nos constat esse velle sapientes, quia nemo sine saoientia beatus est. Nemo enim beatus est nisi summo bono, quod in ea veritate quam sapientiam vocamus cernitur et tenetur." I have followed 
the translation of Anna Benjamin and L.H. Hackstaff, New York: Macmillan Publishing Company, 1964. Pg. 58.

32. Saint Augustine. De Beata Vita; volume 32 of Migne's Patrologia Latina Pg. 132.

33. Saint Augustine. The Enchiridion on Faith, Hope, and Love. Edited by Henry Paolucci and translated by J.F. Shaw, Washington D.C.: Gateway, 1991. Pg. 129. Augustine, in this section of the Enchiridion, speaks of the future reward of heavenly bliss for those good persons along with the future punishment of the wicked. The good of the soul resides in attaining this eternal bliss and avoiding the eternal punishment, but my discussion of happiness has pointed out that there is also a level of happiness which can be achieved in the worldly life. My discussion of happiness as the objective of the soul has emphasized this limited, worldly view. My emphasis has attempted to make clear that happiness, to the greatest extent possible in this life, can be achieved by pursuing wisdom by way of faith, hope, and love.

34. 'Via spiritus' is an expression I'm using to suggest both a turning and progression of the human spirit. Literally, the expression tranlates into English as, "the way of the spirit".

35. Saint Augustine. De Doctrina Christiana. St. Petersburg Manuscript edited by R.P.H. Green as found in Augustine: De Doctrina Christiana edited and translated by R.P.H. Green. Oxford University Press: New York, 1995. Ppg. 62-64. "Deinde mitescere opus est pietate neque contradicere divinae scripturae sive intellectae, si aliqua vitia nostra percutit, sive non intellectae, quasi nos melius sapere meliusque praecipere possimus, sed cogitare potius et credere id esse melius et verius quod ibi scriptum est, etiam si lateat, quam id quod nos per nos ipsos sapere possumus." I have followed the English translation of Edmund Hill. Pg. 132.

36. Saint Augustine. De Doctrina Christiana. St.Petersburg Manuscript edited by R.P.H. Green. Pg. 64. "Nam ista scientia bonae spei hominem non se iactantem sed lamentantem facit; quo affectu impetrat sedulis precibus consolationem divini adiutorii, ne desperatione frangatur." I have followed the english translation of Edmund Hill. Pg. 133. Notice the explicit reference made to divine help (grace). This aid is not only necessary for this stage in the evolution of the spirit, but, since the via spiritus is most certainly able to be characterized as a good, then the whole of the spiritual process must, itself, come from God. Hence, the whole dynamic evolution of the spirit expressed in this "ladder of spiritual love", as a good, is a grace-an unwarranted gift from God. This I think would be Augustine's position. 
37. Saint Augustine. De Doctrina Christiana. Translated by Edmund Hill. New City Press: New York, 1992. Pg. 133.

38. Saint Augustine. De Doctrina Christiana. St. Petersburg Manuscript edited by R.P.H. Green. Ppg. 64-66. "Ubi, iam ipsum oculum purgat quo videri deus potest, quantum potest ab eis qui huic saeculo moriuntur quantum possunt." I have followed the English tranlation of Edmund Hill. Pg. 133.

39. Saint Augustine. De Doctrina Christiana. Pg. 133.

40. Saint Augustine. De Doctrina Christiana. Pg. 133. Notice that this state of wisdom Augustine defines as a "climbing up", a dynamic process forward towards the final stop, "enjoyment in peace and tranquillity."

41. Saint Augustine. The Trinity. Translated by Edmund Hill. New City Press: New York, 1991. Pg. 209. Literally translated, 'sapientia caritatis' is the wisdom of love. In examining the Trinity, Augustine concludes that the blessedness we receive from God constitutes our perfection in the image of God. God is love and loving unity of Father, Son, and Holy Spirit; this is one of the insights of Augustine's journey into the inner life of God. Our blessedness, our happiness, resides in our imaging this Loving Unity. In short, this love is the sapientia caritus which permeates the soul as a gift from God and is an eternal procession flowing forth from God's sacred, unique personality.

42. See part two of Nussbaum's paradigm on page seven.

43. See part four of Nussbaum's paradigm on page seven.

44. See part five of Nussbaum's paradigm on page seven.

45. See part six of Nussbaum's paradigm on page seven.

46. Gilson, Etienne. The Christian Philosophy of Saint Augustine. New York: Random House. 1960. Pg. 148.

47. Saint Augustine. The Enchiridion on Faith, Hope, and Love. Corpus Christianorum series latina XLVI Pg. 54. Augustine writes in the Enchiridion, "Naturae igitur omnes, quoniam naturarum prorsus omnium conditor summe bonus est, bonae sunt. Sed quia non sicut earum conditor summe atque imcommutabiliter bonae sunt, ideo in eis et minui bonum et augeri potest. Sed bono minui malum est, quamuis quantumcumque minuatur remaneat aliquid necesse est, si adhuc natura est, unde natura sit." "All that exists, therefore, seeing that the Creator of them all is supremely good, are themselves good. But because they are not, like their Creator, supremely and unchangeably good, their good may be diminished and increased. But for good to be diminished is an evil, although however much it may be diminished, it is necessary, if the being is to continue, that some good remain to constitute the being." Translation used is that of J.F. Shaw. Pg. 12. This passage makes evi- 
dent that, for Augustine, created being is always created according to the good; if it wasn't good, then it would fall away into nothingness. However, created being, although it is good, is not unchangeably good. It can become better and worse. Created being, therefore, has the potential for perfection, but also corruption. Augustine's interpretation of Genesis also reaffirms this position concerning the effects of potentially corruptible, created being. Human beings in their original state were true to their good creation, but simultaneously, human beings were also liable to corruption, a liability which they eventually did freely choose.

48. Saint Augustine. Of True Religion. trans. by J.H.S. Burleigh. Chicago: Henry Regnery Company, 1966. Pg. 34. In this text, Augustine outlines the event of the fall along with its consequences. He explains that the medium by which the sin occurred, free will, was not itself, intrinsically evil. Instead, the free act of disobedience, the free decision to turn away from God, was, itself, that which was intrinsically evil. And from this disobedient act flowed its deserving penalty-pain, suffering, and ignorance.

49. Gilson, Etienne. The Christian Philosophy of Sain Augustine. Pg. 156. Gilson sums up this position when he writes, "now since the fall, mankind is simply a sinful throng, liable to the supreme justice for the penalty it must pay. Whether God remits the penalty by justifying the culpable or exacts it by abandoning him, no injustice is done. As for deciding who is to pay his penalty and who is to be let off, we are debtors and it is not our place to make that decision. God does not compel some men to sin because He justifies others from sin, and He only justifies some men in virtue of an inscrutable justice, whose motives escape our judgment."

50. Saint Augustine. The Enchiridion on Faith, Hope, and Love. Pg. 66. Augustine comments on this human dependence upon grace. He says, "Item ne quisquam, etsi non de operibus, de ipso glorietur libero uoluntatis arbitrio, tanquam ab ipso incipiat meritum cui tanquam debitum reddatur praemium bene operandi ipsa libertas, audiat eundem gratiae praeconem dicentem: Deus est enim qui operatur in vobis et velle et operari pro bona voluntate." "And further, should anyone be inclined to boast, not indeed of his works but of the freedom of his will, as if the first merit belonged to him, this very liberty of good action being given to him as a reward he had earned, let him listen to this same preacher of grace, when he says: For it is God which worketh in you, both to will and to do of his own good pleasure." Translation by G. F. Shaw. Pg. 39. So, for Augustine, it is God, "which worketh in you", which supplies the person with the ability to do good, and it is through doing this good, it is through loving God and being virtuous in act, that humans find happiness. 
51. Saint Augustine. The Enchiridion on Faith, Hope and Love. Pg. 38.

52. See part three in Nussbaum's paradigm on page seven. In addition, in order to substantiate my claims regarding grace and it's therapeutic nature, see Thomas Holtzen's article, 'The Therapeutic Nature of Grace in St. Augustine's De Gratia et Libero Arbitrio', found in-Augustinian Studies: Volume 31, numberl, 2000 Ppg. 93-115. In his article, Holtzen argues that Augustine is in line with St. Paul in respect to his views on grace and its role in the authentically good and happy life. 'Only grace provides the therapy that heals the will from the disease of sin and empowers it to act out of love.' (Pg. 103) Grace is that method by which eudaemonia is achieved. This is what I am arguing. Without grace, there would be no human happiness because a grace-informed act is behind both the human being along with its coterminous good, but also, since the fall, grace is required to strengthen our crippled selves and restore us to our original condition of loving well. However, this must also be said about grace: for Augustine, grace additionally strengthens our intellects and allows us to acquire knowledge of both God and His created order. Grace helps us to philosophically examine God's creation and discern those life and health giving truths, without which we would continue to persist misguidedly, forever sick, poverty stricken, unhealthy and in need. In short then, for Augustine, grace helps humans to construct the proper arguments which put God's world accurately in focus so that we may understand the truth concerning ourselves, our world, our virtue, our goodness, and our happiness through love.

53. Saint Augustine. Confessiones. Based upon Knoll's (Teubner, 1909) original Latin text. Cambridge: Harvard University Press, 1989. Pg. 60. "Hoc enim peccabam, quod non in ipso, sed in creaturis eius, me atque ita inruebam in dolores, confusiones, errores." I have followed Maria Boulding's translation. Pg. 61. And at the end of Book II, this theme of pain and disorder is again evident. Augustine comments, "Quis experit istam tortuosissimam et inplicatissimam nodositatem? Foeda est; nolo in eam intendere, nolo eam videre. Te volo, iustitia et innocentia, pulchra et decora honestis luminibus, et insatiabili satietate. Quies est apud te valde et vita imperturbabilis. Qui intrat in gaudium domini sui et non timebit et habebit se optime in optimo. Defluxi abs te ego et erravi, deus meus, nimis devius ab stabilitate tua in adulescentia et factus sum mihi regio egestatis." Pg. 94. "Who can unravel this most snarled, knotty tangle? With you is rest and a tranquil life. Whoever enters into you enters into the joy of his Lord; there he will fear nothing and find his own supreme good in God who is supreme goodness. I slid away from you and wandered away, my God; far from your steadfastness I strayed in 
adolescence, and I became to myself a land of famine." Again, I have followed the Maria Boulding translation. Pg. 74.

54. Saint Augustine. Confessiones. Based upon Knoll's (Teubner, 1909) original Latin text. Cambridge: Harvard University Press, 1989. Pg. 288. "Non enim verum gaudium habebat: sed et ego illis ambitionibus multo falsius quaerebam. Et certe ille laetabatur, ego anxuis eram, securus ille, ego trpidus." I have followed Maria Boulding's translation. Pg. 143.

55. Saint Augustine. Confessiones Pg. 462. “...et tu, domine, usquequo? Usqueqo, domine, irasceris in finem? Ne memor fueris iniquitatum nostrarum antiquarum. Sentiebam enim eis me teneri. Iactabam voces miserabiles." I have followed the Maria Boulding translation. Pg. 206.

56. Saint Augustine. Confessiones. Based upon Knoll's (Teubner, 1909) original Latin text. Cambridge: Harvard University Press, 1989. Pg. 464. "Dicebam haec, et flebam, amarissima contritione cordis mei. Et esse audio vocem de vicina domo cum cantu dicentis, et crebro repetentis, quasi pueri an puellae, nescio: 'tolle lege, tolle lege."' I have followed the Maria Boulding translation. Pg. 206.

57. Saint Paul. Romans 14:1.

58. Saint Augustine. Confessiones. Based upon Knoll's (Teubner, 1909) original Latin text. Cambridge: Harvard University Press, 1989. Stans in ea regula fidei. Pg. 466. I have followed the Maria Boulding translation. Pg. 208. He makes reference to the introduction of faith into his life only after he has first recognized his own spiritual death (mortality), and his fear of God before the final judgement. The pattern of via spiritus is being followed.

59. This final virtue of charity is soon made explicit after he describes his infusion in faith and hope.

60. Saint Augustine. Confessiones. Based upon Knoll's (Teubner, 1909) original Latin text. Cambridge: Harvard University Press, 1989. Pg. 48. "...erigentes nos ardentiore affectu in id ipsum, perambulavimus gradatim cuncta corporalia, et ipsum caelum, unde sol et luna et stellae lucent super terram. Et adhuc ascendebamus, interius cogitando et loquendo et mirando opera tua, et venimus in mentes nostras et transcendimus eas, ut attingerein mentes nostras et transcendimus eas, ut attingeremus regionem ubertatis indeficientis, unde pascis Israel in aeternum veritate pabulo..." I have followed the Maria Boulding translation. Pg. 277.

61. Saint Augustine. Confessiones. Based upon Knoll's (Teubner, 1909) original Latin text. Pg. 4. “...iam liber erat animus meus a curis 
mordacibus ambiendi et adquirendi et volutandi atque scalpendi scabiem libidinum." In translation, I have followed Maria Boulding's interpretation of The Confessions. Pg. 210. 